\title{
Structural-Spectroscopic Properties and Antioxidant Activity Studies of Naringenin in Solvent Media
}

\author{
Mustafa Tuğfan BİLKAN ${ }^{1 *}$, Çiğdem BİLKAN ${ }^{1}$
}

\begin{abstract}
In this study, solvent effects on the structural and spectroscopic properties of the naringenin have been investigated. Geometric parameters were calculated and were compared with the experimental X-ray crystallographic data. In addition, optimized structures were obtained in solvent media and the solvents effects on geometric parameters were determined. Vibrational modes obtained in the vacuum and in solvent environments were compared with the experimental IR spectrum. Furthermore, the HOMO-LUMO energies and chemical reactivity were also determined. Antioxidant activity of naringenin has been investigated with hydrogen atom abstraction from - $\mathrm{OH}$ groups. The bond dissociation enthalpies have been calculated and it is determined that this process should be the main mechanism for the antioxidant activity of naringenin. According to the calculation results, surprisingly, it has been found that in DMSO, BDE values of naringenin are significantly reduced and thus antioxidant activity is increased compared to other media.
\end{abstract}

Keywords: Naringenin, Solvent effects, DFT, Chemical reactivity

\section{Naringenin'in Çözücü Ortamlardaki Yapısal-Spektroskopik Özellikleri ve Antioksidan Aktivite Çalışmaları}

ÖZET: Bu çalışmada, naringenin yapısal ve spektroskopik özellikleri üzerine çözücü etkileri araştırılmıştır. Naringenin'in geometrik parametreleri hesaplanmış ve deneysel X-1şını kristalografik verisi ile karşılaştırılmıştır. Ek olarak, çözücü ortamında optimize edilmiş yapılar elde edilerek, çözücülerin geometrik parametreler üzerindeki etkileri belirlendi. Vakumda ve çözücü ortamlarda elde edilen titreşim modları deneysel IR spektrumu ile karşılaştırıldı. Ayrıca, HOMO-LUMO enerjileri ve kimyasal reaktivite de belirlendi. Naringenin antioksidan aktivitesi, -OH gruplarından hidrojen atomu soyutlaması ile araştırıldı. Bağ ayrışma entalpileri hesaplandı ve bu sürecin naringenin antioksidan aktivitesinin ana mekanizması olması gerektiği belirlendi. Hesaplama sonuçlarına göre şaşırtıcı bir şekilde, DMSO'da naringenin BDE değerlerinin önemli ölçüde azaldığı ve dolayısıyla antioksidan aktivitenin diğer ortamlara göre arttığı belirlendi.

Anahtar Klimeler: Naringenin, Çözücü Etkileri, YFT, Kimyasal reaktivite

\footnotetext{
${ }^{1}$ Mustafa Tuğfan BİLKAN (Orcid ID: 0000-0002-0306-1509), Çiğdem BİLKAN (Orcid ID: 0000-0002-3347-673X), Çankır1 Karatekin Üniversitesi, Fen Fakültesi, Fizik Bölümü, 18100, Çankırı, Türkiye

*Sorumlu Yazar/Corresponding Author: Mustafa Tuğfan Bilkan, e-mail: mtbilkan@gmail.com 


\section{INTRODUCTION}

Naringenin $\left(\mathrm{C}_{15} \mathrm{H}_{10} \mathrm{O}_{5}, \mathrm{NRG}\right)$ is one of the most important bioflavonoids. It is found especially in citrus plants and its molar weight is $272.256 \mathrm{~g} / \mathrm{mol}$. NRG is also found in the structure of propolis. It is well known that NRG possesses a broad array of biological activities. It shows anticancer, antioxidant, antiinflammatory, antiviral, antibacterial and antifungal properties at significant levels (Bao et al., 2016; Frabasile et al., 2017; Gonzales et al., 2016; Cavia-Saiz et al.,2010). In addition, due to developer effects on human memory, it is being investigated as a potential treatment for Alzheimer's disease (Ghofrani et al., 2015). Studies on the pharmacological and biological properties of the molecule have gained a significant impetus in the 1990s and are still effective today (Fuhr et al., 1993; PC et al., 2001; Alam et al., 2014).

Many bioflavonoids taken orally in the body, such as NRG, are generally low in absorption after digestion. Materials with such important biological effects are usually extracted from plants using a variety of solvents, and after some purification processes, they are presented for commercial uses. The solvents used for this extraction process are mostly water $\left(\mathrm{H}_{2} \mathrm{O}\right)$, ethanol (EtOH), dimethylsulfoxide (DMSO), chloroform $\left(\mathrm{CHCl}_{3}\right)$, dichloromethane (DCM) etc. that are harmless or slightly harmful to the human body.

The investigation of solvent effects on structural parameters of drugs or pharmacologically active molecules is quite important because solvents can directly affect all physical and chemical properties of any molecule (Bilkan et al., 2017). However, it may be quite difficult to study the solvent effects on molecular structures in terms of computational costs and the complexity of calculations. There are many models for study of solvent effects on molecular structures. One of these methods, which has proven its authenticity and has high reliability, is also Polarizable Continuum Model (PCM). When examining solvent interactions, PCM treats solvents as a continuous polarized environment rather than as individual molecules (Tomasi et al. 2005). In this type of study, the computation costs are relatively low.

In the literature, studies related to NRG generally focus on their pharmacological and biological properties, while little has been done on their interaction with solvents (Zhang et al., 2013; Zhang et al., 2015). As far as we know, there are no studies of solvent effects on NRG. Due to its scientific importance, in this work, some theoretical calculations on the structural and vibrational parameters of the NRG molecule in widely used solvent environments have been made. Density Functional Theory was used in quantum chemical calculations. Theoretically, obtained data are compared with the experimental results from the literature. In addition, frontier orbitals, chemical reactivity and molecular electrostatic potential map have also been determined. The results obtained were discussed and the effects of solvent environments on NRG molecule were elucidated in detail.

\section{MATERIAL AND METHODS}

All calculations performed in vacuum and solvent media were made DFT/6-311++G(d,p) method on a high-capacity computer by using Gaussian03 program with the help of Gaussview visualization program (Frisch et al., 2004; Dennington et al., 2008). The calculated frequencies were scaled by 0.97 to correct the difference between the calculated and experimental vibrational frequencies. The fundamental vibrational modes were characterized by their PED (potential energy distribution) obtained by using the VEDA4 program (Jamróz, 2004). 


\section{RESULTS AND DISCUSSION}

\section{Molecular structure optimization and geometric parameters}

Optimizations of the geometric structures were performed with the calculation level B3LYP/6-311++G(d,p) and the optimized structure was given in Figure 1.

of the NRG in vacuum and solvent environments

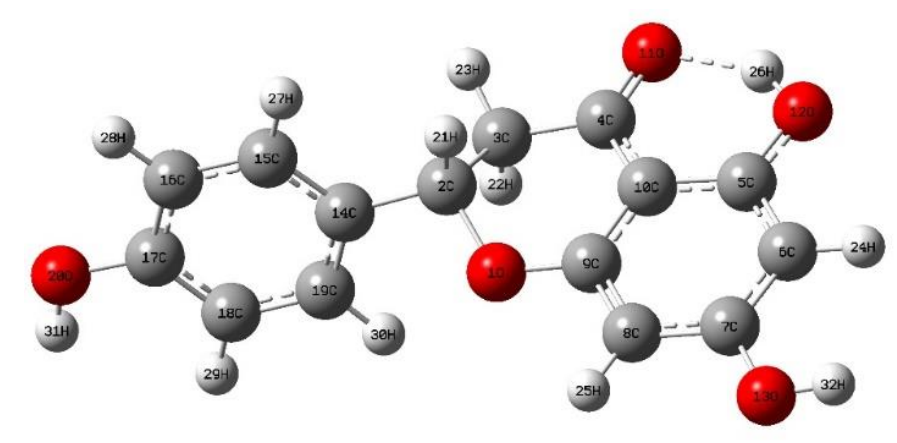

Figure 1. Optimized molecular structure of NRG

Additionally, the calculated and experimental (Shin et al., 1986) molecular parameters of the structure were given in Table 1.

As shown from Table 1, the bond distance between the $11 \mathrm{O}-26 \mathrm{H}$ atoms is approximately 1.70-1.80 $\AA$. This distance is lower than the sum of the van der Waals radii of hydrogen and oxygen atoms (Pauling, 1960). This shows that there are intramolecular hydrogen bonds between the $110-26 \mathrm{H}$ atoms. According to Table 1, the length of this hydrogen bond does not change regularly in solvent environments. It decreases as it passes from vacuum to chloroform and increases from chloroform to ethanol. However, the changes are less than just 0.01 for all environments. In fact, although the atomic charges of the $11 \mathrm{O}$ and $26 \mathrm{H}$ atoms undergo significant changes from the solvent environments, the hydrogen bond length exhibits small increases or decreases as the cavity boundaries of the solvents create a dielectric environment between these two atoms. As a result, the effect of changing solvent polarity on the intramolecular hydrogen bond of NRG is very limited. When the table is examined, it is also clear that all calculated geometric parameters are in good agreement with the experimental parameters. For all bond lengths, outside the $\mathrm{C}-\mathrm{H}$ and $\mathrm{O}-\mathrm{H}$ bond lengths, the deviations between the calculated and the experimental values are less than $0.1 \AA$. Singlecrystal X-ray experiments have proven to be an experimental error in the measurement of $\mathrm{C}-\mathrm{H}$, $\mathrm{N}-\mathrm{H}$ and $\mathrm{O}-\mathrm{H}$ bonds due to $\mathrm{X}$-ray scattering factors (Lee et al., 1996).

The $4 \mathrm{C}=11 \mathrm{O}$ bond is double bonded and there is a $0.018 \AA$ deviation between the calculated value and the X-ray data. Although such this deviation is insignificant, it is bigger than other deviations between calculated and experimental geometric parameters. The reason for this is the intermolecular hydrogen bonds between 110 and hydrogen atoms in the crystal structure. Due to these bonds, the measured $\mathrm{C}=\mathrm{O}$ value is larger than the calculated. In Table 2 , the calculated values of the dihedral angles of 14C-2C-3C-4C and 15C-14C-2C-1O are - 175.35 and 132.62, respectively. This shows that NRG is non-planar in vacuum and solvent media. 
Table 1. Optimized bond lengths and bond angles of NRG in different media (selected).

\begin{tabular}{|c|c|c|c|c|c|c|}
\hline Lengths $(\AA)$ & Vacuum & $\mathrm{CHCl}_{3}$ & $\mathrm{EtOH}$ & DMSO & $\mathrm{H}_{2} \mathrm{O}$ & Exp.* \\
\hline $1 \mathrm{O}-2 \mathrm{C}$ & 1.452 & 1.461 & 1.461 & 1.465 & 1.465 & 1.455 \\
\hline $10-9 \mathrm{C}$ & 1.359 & 1.357 & 1.357 & 1.357 & 1.356 & 1.370 \\
\hline $2 C-3 C$ & 1.530 & 1.528 & 1.528 & 1.527 & 1.527 & 1.509 \\
\hline $2 C-14 C$ & 1.507 & 1.506 & 1.507 & 1.506 & 1.506 & 1.510 \\
\hline $2 \mathrm{C}-21 \mathrm{H}$ & 1.097 & 1.098 & 1.099 & 1.099 & 1.099 & 1.116 \\
\hline $3 \mathrm{C}-4 \mathrm{C}$ & 1.515 & 1.512 & 1.511 & 1.511 & 1.511 & 1.503 \\
\hline $3 \mathrm{C}-22 \mathrm{H}$ & 1.097 & 1.098 & 1.098 & 1.098 & 1.098 & 0.949 \\
\hline $4 C-10 C$ & 1.446 & 1.444 & 1.442 & 1.442 & 1.442 & 1.434 \\
\hline $4 C=11 O$ & 1.238 & 1.243 & 1.245 & 1.245 & 1.245 & 1.256 \\
\hline $5 C-6 C$ & 1.390 & 1.387 & 1.386 & 1.386 & 1.386 & 1.380 \\
\hline $5 C-10 C$ & 1.427 & 1.427 & 1.427 & 1.427 & 1.427 & 1.420 \\
\hline $5 \mathrm{C}-12 \mathrm{O}$ & 1.338 & 1.344 & 1.347 & 1.347 & 1.347 & 1.353 \\
\hline 6C-7C & 1.393 & 1.398 & 1.399 & 1.400 & 1.400 & 1.385 \\
\hline $6 \mathrm{C}-24 \mathrm{H}$ & 1.081 & 1.084 & 1.086 & 1.086 & 1.086 & 0.971 \\
\hline $7 \mathrm{C}-13 \mathrm{O}$ & 1.359 & 1.354 & 1.352 & 1.352 & 1.352 & 1.365 \\
\hline $110 \cdots 26 \mathrm{H}$ & 1.719 & 1.715 & 1.717 & 1.713 & 1.719 & 1.880 \\
\hline $12 \mathrm{O}-26 \mathrm{H}$ & 0.988 & 0.989 & 0.989 & 0.989 & 0.989 & 0.863 \\
\hline $13 \mathrm{O}-27 \mathrm{H}$ & 0.964 & 0.976 & 0.983 & 0.984 & 0.986 & 0.825 \\
\hline $15 \mathrm{C}-28 \mathrm{H}$ & 1.085 & 1.087 & 1.088 & 1.088 & 1.088 & 1.104 \\
\hline $17 \mathrm{C}-20 \mathrm{O}$ & 1.367 & 1.366 & 1.365 & 1.364 & 1.365 & 1.379 \\
\hline $18 \mathrm{C}-19 \mathrm{C}$ & 1.391 & 1.391 & 1.392 & 1.392 & 1.391 & 1.393 \\
\hline $19 \mathrm{C}-31 \mathrm{H}$ & 1.084 & 1.086 & 1.087 & 1.088 & 1.088 & 0.884 \\
\hline Angles $\left(^{\circ}\right)$ & Vacuum & $\mathrm{CHCl}_{3}$ & EtOH & DMSO & $\mathrm{H}_{2} \mathrm{O}$ & Exp.* \\
\hline $14 \mathrm{C}-2 \mathrm{C}-3 \mathrm{C}-4 \mathrm{C}$ & -175.35 & -175.29 & -174.79 & -174.67 & -174.92 & -172.94 \\
\hline $15 \mathrm{C}-14 \mathrm{C}-2 \mathrm{C}-1 \mathrm{O}$ & 132.62 & 120.45 & 126.14 & 127.37 & 116.82 & 120.51 \\
\hline
\end{tabular}

*Data were taken from (Shin et al., 1986)

Due to the changing environment, it can be seen that some bond lengths undergo serious changes while others have little affected. For example, in the passing from vacuum to water, while $5 \mathrm{C}-12 \mathrm{O}$ bond length has a change of 0.009 $\AA$, a change of $0.004 \AA$ in the $5 \mathrm{C}-6 \mathrm{C}$ bond has occurred. This is because the arrangement of atoms in the plane of the ring is more stable than the atoms outside the plane of the ring, and as a result, they are minimally affected by changing physical conditions such as temperature, pressure and solvent environment.

\section{Vibrational frequencies and assignments}

The NRG has 32 atoms and 90 fundamental vibrational modes. The calculated and experimental (Unsalan et al., 2008) IR spectra of NRG were given in Figure 2. Additionally, some significant vibrational modes of NRG were given in Table 2 with detailed assignments.
It is seen that the modes calculated and experimental in Table 2 perfectly match each other. There is some little mismatches in the range of $3000-3500 \mathrm{~cm}^{-1}$ where the $\mathrm{C}-\mathrm{H}$ and $\mathrm{O}$ $\mathrm{H}$ vibrations are observed. The reason of this is that while the theoretical calculations are conducted for a single molecule in vacuum, the experimental spectrum is recorded in the solid phase and there are many intra and intermolecular interactions. Especially, intermolecular hydrogen bonds cause the $\mathrm{C}-\mathrm{H}$, $\mathrm{N}-\mathrm{H}$ and $\mathrm{O}-\mathrm{H}$ modes to shift to lower frequencies.As can be seen from Table 2, the modes calculated at $3718-3712$ and $3232 \mathrm{~cm}^{-1}$ correspond to $\mathrm{O}-\mathrm{H}$ stretching modes, which were observed at 3410 (broad) and $3129 \mathrm{~cm}^{-1}$ in the experimental spectrum. The mode calculated at $3718 \mathrm{~cm}^{-1}$ corresponds to the vibrations between atoms 280-32H. The mode calculated at 3712 $\mathrm{cm}^{-1}$ is the vibrations between $13 \mathrm{O}-27 \mathrm{H}$ atoms 
and finally the mode calculated at $3232 \mathrm{~cm}^{-1}$ refers to vibrations between the $12 \mathrm{O}-26 \mathrm{H}$ atoms. The first two modes are very close to each other, while the third mode is far away because of the hydrogen bonding between $26 \mathrm{H}-11 \mathrm{O}$ atoms. This bonding has shifted this vibration to 3232 $\mathrm{cm}^{-1}$. The stretching mode between the $11 \mathrm{O}=4 \mathrm{C}$ atoms was calculated at $1628 \mathrm{~cm}^{-1}$ in vacuum and observed at $1658 \mathrm{~cm}^{-1}$. At the same time, it is the most intense vibrational mode in the experimental spectrum. The C-C vibrational modes have calculated together with various bending modes in the range of $1500-1600 \mathrm{~cm}^{-1}$ in accordance with the literature. When Table 2 is examined, free $\mathrm{O}-\mathrm{H}$ stretching vibrations calculated at 3718 and $3712 \mathrm{~cm}^{-1}$ shifted to 3283 and $3257 \mathrm{~cm}^{-1}$ in water environment. The hydrogen bonded $\mathrm{O}-\mathrm{H}$ vibrational mode calculated at $3232 \mathrm{~cm}^{-1}$ has shifted to $3201 \mathrm{~cm}^{-1}$. This shows that the bonded $\mathrm{O}-\mathrm{H}$ stretching vibrations are less affected by the changing physical conditions compared to the free ones. Unlike O-H vibrations, C-H vibrations have shifted in the range of only $20-75 \mathrm{~cm}^{-1}$ in solvent environments. The stretching vibration between $110-4 \mathrm{C}$ atoms calculated at $1628 \mathrm{~cm}^{-1}$ showed $28 \mathrm{~cm}^{-1}$ shift. However, this vibration has calculated as the most severe band in solvent environments as in the gas phase. As can be seen, all the vibrational modes calculated with DFT/B3LYP/6-311++G(d,p) are in agreement with the experimental data.

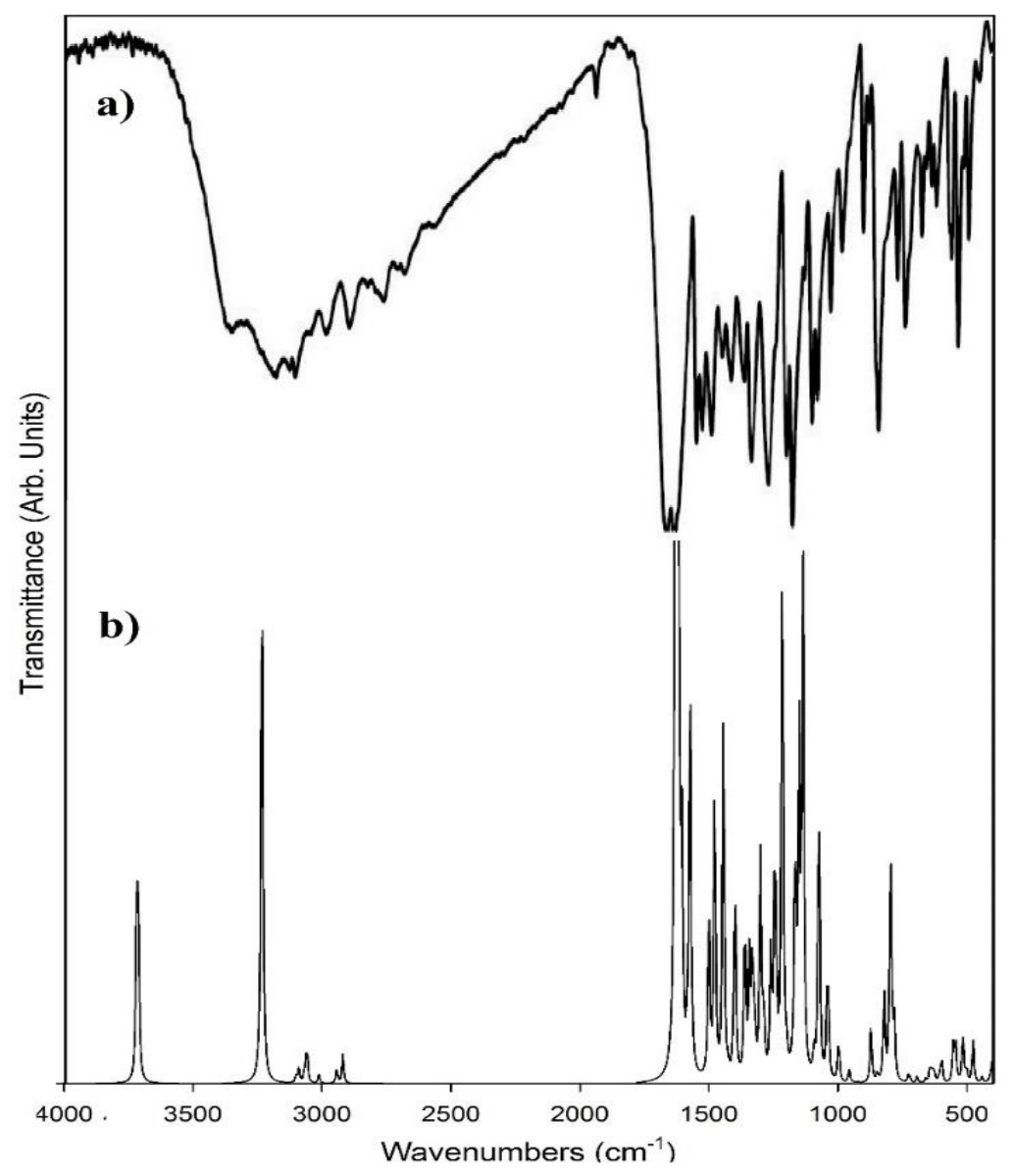

Figure 2. a) Experimental and b) calculated IR spectra of NRG (the experimental spectrum was taken from Unsalan et al., 2008) 
Table 2. The calculated and experimental selected vibrational modes of NRG in different media.

\begin{tabular}{|c|c|c|c|c|c|c|c|c|c|c|c|c|}
\hline \multirow{2}{*}{ Mode } & \multicolumn{2}{|c|}{ Vacuum } & \multicolumn{2}{|c|}{$\mathrm{CHCl}_{3}$} & \multicolumn{2}{|c|}{ EtOH } & \multicolumn{2}{|c|}{ DMSO } & \multicolumn{2}{|c|}{ Water } & \multirow{2}{*}{ Exp.* } & \multirow[b]{2}{*}{$\operatorname{PED}(\%)^{* * *}$} \\
\hline & req. & Rel. IR & Freq. & Rel. IR & req. & . Rel. IR & Freq. & Rel. IR & Freq. & Rel. IR & & \\
\hline 19 & 410 & 0.44 & 412 & 0.57 & 412 & 0.43 & 413 & 0.66 & 413 & 0.77 & 420 & $\Gamma_{\mathrm{CCCC}}(66)$ \\
\hline 20 & 442 & 0.41 & 441 & 0.53 & 442 & 0.61 & 442 & 0.70 & 441 & 0.72 & 449 & $\delta_{\mathrm{CCC}}(19)+\delta_{\mathrm{CCO}}(11)+\mathrm{V}_{\mathrm{CC}}(10)$ \\
\hline 21 & 476 & 3.36 & 475 & 4.75 & 476 & 4.59 & 475 & 5.35 & 475 & 5.70 & 463 & $\delta_{\mathrm{OCC}}(29)+\delta_{\mathrm{CCC}}(17)$ \\
\hline 22 & 501 & 0.96 & 501 & 0.45 & 502 & 0.64 & 501 & 0.30 & 501 & 0.38 & 483 & $\Gamma_{\text {OссC }}(16)$ \\
\hline 23 & 516 & 4.07 & 517 & 6.80 & 516 & 7.13 & 518 & 8.72 & 517 & 9.14 & 519 & $\Gamma_{\mathrm{OCCC}}(14)+\delta_{\mathrm{OCC}}(12)+\Gamma_{\mathrm{HCCC}}(11)$ \\
\hline 24 & 544 & 3.05 & 544 & 4.04 & 544 & 4.03 & 544 & 4.07 & 544 & 4.67 & 557 & $\delta_{\mathrm{CCC}}(19)+\delta_{\mathrm{OCC}}(11)$ \\
\hline 25 & 553 & 2.72 & 552 & 3.61 & 552 & 3.23 & 553 & 4.63 & 552 & 41 & 568 & $\delta_{\mathrm{OCC}}(23)+\delta_{\mathrm{CCC}}(17)$ \\
\hline 26 & 598 & 1.95 & 598 & 2.57 & 599 & 2.37 & 599 & 2.80 & 598 & 99 & 596 & $\Gamma_{\mathrm{OCCC}}(31)$ \\
\hline 28 & 625 & 0.61 & 626 & 0.65 & 626 & 0.73 & 626 & 0.89 & 625 & 10 & 616 & $\Gamma_{\mathrm{OCCC}}(1 \mathrm{C}$ \\
\hline 29 & 633 & 1.02 & 635 & 1.69 & 636 & 1.97 & 636 & 2.33 & 636 & 2.59 & 638 & $\Gamma_{\mathrm{OCO}}$ \\
\hline 32 & 693 & 0.49 & 695 & 0.99 & 695 & 1.20 & 696 & 1.40 & 695 & 1.66 & 680 & $V_{\mathrm{CC}}(17)$ \\
\hline 34 & 726 & 0.64 & 726 & 1.57 & 725 & 1.53 & 726 & 0.91 & 726 & 1.07 & 729 & $\Gamma_{\mathrm{OCCC}}(19)+\Gamma_{\mathrm{CCCC}}(1$ \\
\hline 35 & 782 & 5.07 & 755 & 15.47 & 735 & 8.04 & 736 & 11.24 & 731 & 2.23 & 745 & $\Gamma_{\mathrm{HCCC}}(56)+\Gamma_{\mathrm{CCOC}}(15)+\Gamma_{\mathrm{OCCC}}(14)$ \\
\hline 39 & 821 & 6.72 & 813 & 2.49 & 810 & 3.13 & 809 & 3.47 & 808 & 4.02 & 824 & $\Gamma_{\mathrm{HCCC}}(54)+\Gamma_{\mathrm{OCCC}}(16)$ \\
\hline 41 & 847 & 0.63 & 844 & 0.45 & 844 & 0.60 & 843 & 0.52 & 842 & 0.46 & 853 & $\delta_{\mathrm{CCC}}(17)$ \\
\hline 42 & 872 & 4.45 & 864 & 7.40 & 864 & 6.23 & 861 & 8.32 & 860 & 8.65 & 896 & 2) \\
\hline 44 & 942 & 0.03 & 944 & 0.15 & 947 & 0.79 & 946 & 1.69 & 945 & & & $\Gamma_{\mathrm{HCC}}$ \\
\hline 45 & 957 & 1.09 & 950 & 1.64 & 949 & 1.17 & 949 & 0.72 & 948 & & 9 & \\
\hline 46 & 996 & 1.99 & 993 & 5.00 & 991 & 4.73 & 991 & 6.34 & 990 & & & \\
\hline 48 & 1037 & 4.45 & 1035 & 16.31 & 1034 & 15.89 & 1034 & 21.57 & 1034 & 23.29 & 1019 & $V_{\text {OC }}(15)$ \\
\hline 50 & 1074 & 23.37 & 1067 & 25.90 & 1065 & 24.40 & 1064 & 26.58 & 1064 & 27.92 & 1083 & $\mathrm{~V}_{\mathrm{OC}}(47)$ \\
\hline 52 & 1136 & 39.73 & 1129 & 63.18 & 1127 & 65.73 & 1126 & 76.07 & 1125 & 79.31 & 1102 & $\delta_{\mathrm{HCC}}(38)+\mathrm{V}_{\mathrm{OC}}(21)+\delta_{\mathrm{HOC}}(19)$ \\
\hline 53 & 1150 & 24.60 & 1148 & 29.79 & 1146 & 20.76 & 1146 & 23.12 & 1145 & 26.31 & 1161 & $\delta_{\mathrm{HOC}}(23)+\mathrm{V}_{\mathrm{CC}}(12)+\delta_{\mathrm{HCC}}(11)$ \\
\hline 56 & 1166 & 18.16 & 1167 & 24.92 & 1168 & 29.73 & 1168 & 34.21 & 1168 & 31.26 & 1183 & $\delta_{\mathrm{HCC}}(28)+\Gamma_{\mathrm{HCCC}}(10)$ \\
\hline 58 & 1216 & 44.35 & 1210 & 48.39 & 1209 & 44.52 & 1209 & 47.09 & 1206 & 48.26 & 1211 & $\delta_{\mathrm{HOC}}(40)+\delta_{\mathrm{HCC}}(12)$ \\
\hline 60 & 1244 & 18.63 & 1241 & 8.62 & 1242 & & 1241 & 7.14 & 1241 & & & Vo \\
\hline 62 & 1288 & 5.25 & 1282 & 19.11 & 1279 & 26.13 & 1278 & 31.09 & 1277 & 34.78 & 1283 & $V_{\mathrm{CC}}(16)$ \\
\hline 63 & 1301 & 17.66 & 1294 & 23.26 & 1291 & 22.01 & 1292 & .35 & 1292 & 5.19 & 296 & $V_{O C}(10)$ \\
\hline 64 & 1322 & 4.03 & 1321 & 7.25 & 1320 & & 1320 & .05 & 1319 & 15 & 1335 & $\delta_{\mathrm{HCC}}(35)+\delta_{\mathrm{HOC}}(20)+\mathrm{V}_{\mathrm{CC}}(14)$ \\
\hline 68 & 1399 & 16.20 & 1381 & 26.13 & 1374 & 24.16 & 1374 & 28.54 & 1370 & 26.70 & 1388 & $\delta_{\mathrm{HOC}}(28)+\mathrm{V}_{\mathrm{CC}}$ \\
\hline 71 & 1444 & 29.02 & 1434 & 28.17 & 1431 & 25.79 & 1430 & 28.98 & 1430 & 31.13 & 1452 & $\delta_{\mathrm{HCC}}(16)+\delta_{\mathrm{CC}}$ \\
\hline 72 & 1478 & 23.33 & 1466 & 27.05 & 1460 & 25.08 & 1460 & 28.90 & 1458 & 28.26 & 1472 & $\mathrm{~V}_{\mathrm{CC}}(26)+\delta_{\mathrm{HCC}}(21)+\delta_{\mathrm{HOC}}(17)$ \\
\hline 73 & 1500 & 13.41 & 1494 & 15.52 & 1490 & 15.68 & 1490 & 17.28 & 1489 & 18.37 & 1504 & $\delta_{\mathrm{HCC}}(53)+\mathrm{V}_{\mathrm{CC}}(11)$ \\
\hline 74 & 1573 & 34.00 & 1558 & 37.36 & 1552 & 35.06 & 1551 & 40.33 & 1550 & 41.22 & 1563 & $\mathrm{~V}_{\mathrm{CC}}(33)+\delta_{\mathrm{HOC}}(11)$ \\
\hline 75 & 1585 & 1.46 & 1579 & 4.13 & 1577 & 11.41 & 1575 & 33.01 & 1574 & 77.09 & 1583 & $\mathrm{~V}_{\mathrm{CC}}(42)+\delta_{\mathrm{CCC}}(11)$ \\
\hline 76 & 1605 & 15.43 & 1593 & 92.38 & 1581 & 85.04 & 1578 & 91.67 & 1577 & 62.83 & - & $V_{\mathrm{CC}}(59)$ \\
\hline 77 & 1618 & 41.64 & 1597 & 17.04 & 1593 & 17.11 & 1593 & 19.61 & 1592 & 21.76 & 1618 & $\mathrm{~V}_{\mathrm{OC}}(27)+\mathrm{V}_{\mathrm{CC}}(17)$ \\
\hline 78 & 1628 & 100.00 & 1608 & 100.00 & 1603 & 3100.00 & 1602 & 100.00 & 1600 & 100.00 & 1658 & $\mathrm{~V}_{\mathrm{OC}}(64)+\mathrm{V}_{\mathrm{CC}}(12)+\delta_{\mathrm{HOC}}(10)$ \\
\hline 80 & 2943 & 1.12 & 2929 & & 2921 & 10.28 & 2922 & 0.28 & 2921 & 0.30 & & $\mathrm{~V}_{\mathrm{CH}}(92)$ \\
\hline 82 & 3058 & 2.87 & 3028 & 0.80 & 3014 & 0.34 & 3011 & 0.38 & 3010 & 0.36 & 30 & $\mathrm{~V}_{\mathrm{CH}}(93)$ \\
\hline 84 & 3089 & 0.3 & 3049 & 0.06 & 3033 & 0.74 & 3029 & 0.16 & 3027 & 0.22 & 308 & \\
\hline 85 & 3090 & & 3051 & 0.35 & 3033 & & 3030 & 1.3 & 3029 & 1.47 & & $\mathrm{~V}_{\mathrm{CH}}(93)$ \\
\hline 87 & 3120 & 0.0 & 3069 & 0.71 & 3049 & & 3046 & 1.31 & 3045 & 1.36 & 3095 & $\mathrm{~V}_{\mathrm{CH}}(100)$ \\
\hline 88 & 3232 & 46.11 & 3209 & 62.43 & 3206 & 62.85 & 3198 & 72.81 & 3201 & 77.05 & 3129 & $\mathrm{~V}_{\mathrm{OH}}(99)$ \\
\hline 89 & 3712 & 12.77 & 3455 & 43.17 & 3304 & 57.33 & 3283 & 67.96 & 3257 & 73.19 & & $\mathrm{~V}_{\mathrm{OH}}(100)$ \\
\hline 90 & 3718 & 11.54 & 3467 & 35.83 & 3327 & 45.76 & 3305 & 54.64 & 3283 & 58.91 & & $\mathrm{~V}_{\mathrm{OH}}(100)$ \\
\hline
\end{tabular}

* The experimental data were taken from (Unsalan et al., 2008). Rel. IR: Relative IR intensities $* * \mathrm{~V}$ : stretching modes; $\delta$ : bending modes; $\Gamma$ : torsional vibration modes

Since the frequencies of the vibrational modes are not only dependent on the molecular structure but also on the physical conditions, it is expected that the pressure, temperature and solvent environment will influence the geometric parameters and hence the vibration frequencies. 
The calculated $\mathrm{O}-\mathrm{H}$ and $\mathrm{C}-\mathrm{H}$ modes of the NRG in the solvent environment have shifted to lowwavenumbers regions compared to the vacuum environment. These modes have more affected by the solvent environment and other changing physical conditions because they are outside the ring planes as mentioned above.

\section{Frontier molecular orbitals, chemical reactivity and molecular electrostatic potential}

In this paper, the HOMO-LUMO energies of NRG and the energy gap between these two

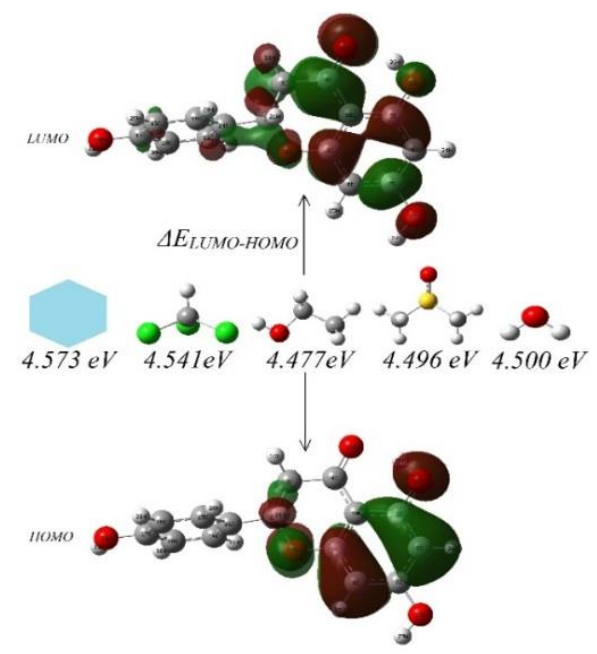

were calculated in vacuum and solvent media. These parameters are quite important because they can explain many physical and chemical properties of the molecule. They are also used to identify chemical reactivity. The ionization potential is directly related to the HOMO, while the electron affinity is related to LUMO. This is also used by the frontier electron density for estimating the most reactive position in $\mathrm{p}$ electron systems and explains several types of reaction in the conjugated system (Choi et al., 1997).

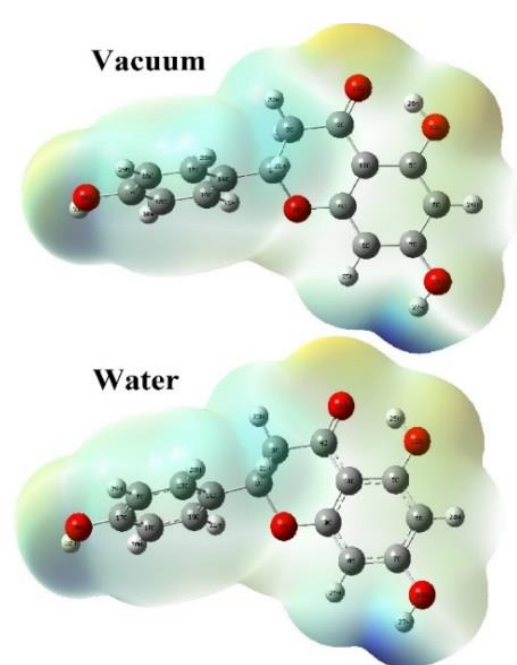

Figure 3. HOMO- LUMO contour maps and energy gaps of NRG in vacuum and solvent media together with the molecular electrostatic potential maps.

HOMO-LUMO contour maps and energy gaps of NRG are shown in Figure 3. It can be seen from Figure 3 that there is a bonding character between the atoms $3 \mathrm{C}-4 \mathrm{C}-10 \mathrm{C}$ and $6 \mathrm{C}$ $5 \mathrm{C}-9 \mathrm{C}$ in the LUMO orbital. In addition, this character is observed between atoms $8 \mathrm{C}-9 \mathrm{C}$ $25 \mathrm{H}, 5 \mathrm{C}-6 \mathrm{C}-24 \mathrm{H}$ and $12 \mathrm{O}-26 \mathrm{H}$ in the HOMO orbital.

The MEP surface is a drawing that visualizes a molecule's shape, size, and charge distribution in three dimensions. Often, the red regions on the map represent the most electron density resides, while the blue regions represent the least electron density resides. In addition, this map contains important information about the nature of molecular bonds. Figure 3 also shows the molecular electrostatic potential map for NRG in vacuum. As you can see from the figure, in the MEP map completely blue or red areas are not very dominant. The positive charge densities have localized on 27 and 32 hydrogen atoms. The 110,120 and 200 are very rich in negative charge. The NBO calculated atomic charges of $11 \mathrm{O}, 12 \mathrm{O}, 20 \mathrm{O}, 26 \mathrm{H}$ and $27 \mathrm{H}$ atoms in vacuum are $-0.624 \mathrm{e},-0.664 \mathrm{e},-0.655 \mathrm{e}, 0.503 \mathrm{e}$ and $0.471 \mathrm{e}$ respectively whereas in solvent environments these values are $-0.674 \mathrm{e},-0.694 \mathrm{e}$, $0.691 \mathrm{e}, 0.507 \mathrm{e}$ and $0.528 \mathrm{e}$. As can be seen here, solvent environments have caused serious changes in atomic charges.

Calculated HOMO-LUMO energies and chemical reactivity of NRG were given in Table 4 together with dipole moments. The electronic properties of the molecules have calculated from 
considering total energies and Koopmans' theorem. Ionization potential $I=-E_{\text {НОмO }}$ and electron affinity $A=-E_{L U M O}$ can be described. Parr et al. (Parr et al., 1999) explained to chemical potential as $\mu=\left(E_{\text {HOMO }}+E_{L U M O}\right) / 2$, chemical hardness as $\eta=\left(E_{L U M O}-E_{\text {HOMO }}\right) / 2$ and finally electrophilicity as $\omega=\mu^{2} / 2 \eta$.

Table 3. Calculated HOMO-LUMO energies, chemical reactivity $(\mathrm{eV})$ and dipole moments of NRG in solvent media.

\begin{tabular}{lccccc}
\hline Parameters & Vacuum & $\mathbf{C H C l}_{\mathbf{3}}$ & $\mathbf{E t O H}$ & DMSO & $\mathbf{H}_{\mathbf{2}} \mathbf{O}$ \\
\hline $\mathrm{E}_{\text {LUMO }}$ & -1.883 & -1.902 & -1.919 & -1.922 & -1.914 \\
$\mathrm{E}_{\text {HOMO }}$ & -6.456 & -6.443 & -6.396 & -6.418 & -6.414 \\
$\Delta \mathrm{E}_{\text {LUMO-HOMO }}$ & 4.573 & 4.541 & 4.477 & 4.496 & 4.500 \\
electron affinity $(\mathrm{A})$ & 1.883 & 1.902 & 1.919 & 1.922 & 1.914 \\
ionization potential $(\mathrm{I})$ & 6.456 & 6.443 & 6.396 & 6.418 & 6.414 \\
global hardness $(\eta)$ & 2.287 & 2.270 & 2.238 & 2.248 & 2.250 \\
chemical potential $(\mu)$ & -4.170 & -4.172 & -4.157 & -4.170 & -4.164 \\
electrophilicity $(\omega)$ & 3.802 & 3.834 & 3.861 & 3.868 & 3.853 \\
$\mu$ (Debye) & 5.1455 & 6.6579 & 7.2558 & 7.3144 & 7.3435 \\
\hline
\end{tabular}

When Table 3 is examined, with the increasing the dielectric constant, it can be seen that there is no regular change in HOMO and LUMO energies. However, the dipole moment of NRG increases regularly with increasing dielectric constant. The changing charge delocalization directly affects the dipole moments of molecules. With the increase of the polarity of the solvents, the charge delocalization of the molecule increases and therefore the dipole moment increases. The HOMO-LUMO gaps of NRG in solvent media were calculated as 4.573, 4.541, 4.477, 4.496 and $4.500 \mathrm{eV}$ respectively. While the increase of HOMOLUMO gap increases the global hardness, the decrease also reduces the global hardness. For this reason, a molecule with a large HOMOLUMO gap is a hard molecule while a small HOMO-LUMO gap is a soft molecule. Furthermore, the stability of a molecule is also related to hardness, since molecules with smaller gaps are more stable while molecules with larger gaps are more reactive. In this case, it can be said that in solvent media the stability of NRG molecule increases compared to vacuum and the chemical hardness decreases.

\section{Antioxidant activity}

In phenolic compounds, the breaking of the O-H bonds of hydroxyl group results in free radicals and the break energy of the bonds is defined as the bond dissociation energy (BDE). The calculation of BDE gives direct useful information about the antioxidant activity of compounds and for this reason, BDE has critical importance to explain the antioxidant activity of NRG. The NRG has three hydroxyl groups. The antioxidant activity of NRG was determined by calculation of the BDE values of these hydroxyl groups.
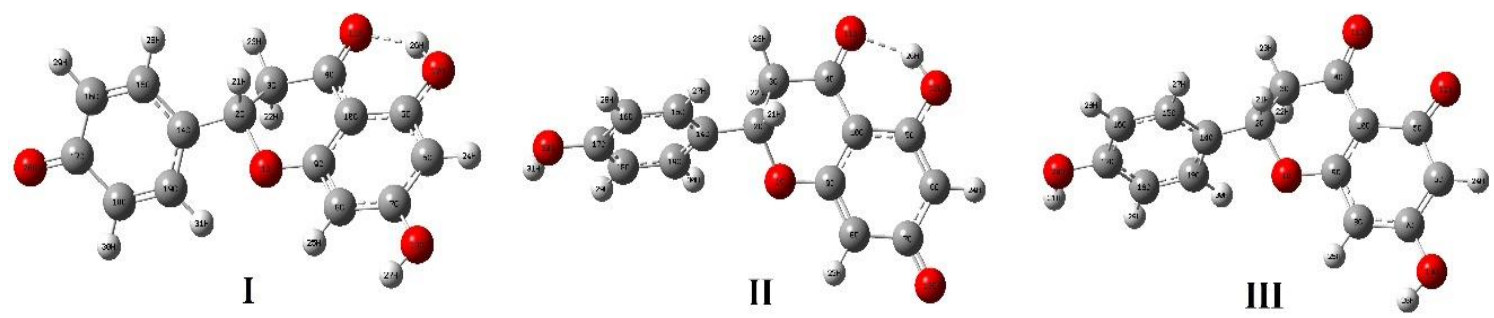

Figure 4. Geometric structures of NRG radicals 
Table 4. Calculated BDE values of NRG radicals in solvent media.

\begin{tabular}{llllll}
\hline Structures & Vacuum & $\mathbf{C H C l}_{\mathbf{3}}$ & EtOH & DMSO & $\mathbf{H}_{\mathbf{2}} \mathbf{O}$ \\
\hline R-1 & 84.35 & 85.71 & 86.59 & 86.79 & 86.96 \\
R-2 & 89.62 & 91.31 & 93.11 & 93.21 & 93.43 \\
R-3 & 99.57 & 94.98 & 92.90 & 78.35 & 92.52 \\
\hline
\end{tabular}

The resulting structures from the breaking of $\mathrm{O}-\mathrm{H}$ bonds were given in Figure 4 and the BDE values calculated for these structures are shown in Table 4.

The BDE values were calculated according to the procedure in the literature (Saqib et al., 2015). When the scheme is examined, the BDE value calculated for R-1 in the vacuum is found to be $84.35 \mathrm{Kcal} / \mathrm{mol}$. The calculated value for $\mathrm{R}$ 2 is $89.62 \mathrm{Kcal} / \mathrm{mol}$ and finally for R-3 is 99.57 $\mathrm{Kcal} / \mathrm{mol}$. BDE values for flavonoids range from 70-90 Kcal $/ \mathrm{mol}$ (Swanson et al., 1985). The lower the BDE value, the higher the antioxidant potential is. In this case, it can be said that the antioxidant property of NRG is derived from the R-1 structure. In addition, the effects of solvents on antioxidant activity are shown in the table. Antioxidant activities of the structures are reduced with increasing solvent polarity since solvent environments increase BDE values of $\mathrm{O}$ $\mathrm{H}$ bonds. However, a very interesting case is that in the DMSO, the BDE values of the R-1 and R-2 increase while BDE value of the R-3 significantly decreases, according to the calculations made. This implies that NRG may show higher antioxidant activity in DMSO than all other solvent media. This may indicate that DMSO can be a useful solvent in antioxidant activity studies of NRG on living tissues. Although DMSO may have some side effects on live cells, it is sometimes known to be used in a number of medical applications (Swanson et al., 1985).

\section{CONCLUSION}

In this paper, theoretical studies on NRG were performed using DFT. The molecular parameters and vibrational modes of NRG were calculated and they were compared with the experimental results from the literature. Solvent effects on all calculated parameters were investigated. From the results of the study, it has been observed that the changing solvent environments have considerable changes in the molecular geometric parameters and the vibrational frequencies. All of the vibrational modes calculated in the DFT were in good agreement with the experimental ones. The antioxidant activity of NRG was studied theoretically and it was found that the antioxidant potential could be derived from the R-1 structure. It has also been determined that in DMSO, BDE values of naringenin are significantly reduced and antioxidant activity is increased in this medium compared to other solvent media.

\section{REFERENCES}

Alam MA, Subhan N, Rahman MM, Uddin SJ, Reza HM, Sarker SD, 2014. Effect of Citrus Flavonoids, Naringin and Naringenin, on Metabolic Syndrome and Their Mechanisms of Action, Advances in Nutrition. 5: 404-417.

Bao L, Liu F, Guo HB, Li Y, Tan BB, Zhang WX, Peng $Y$, 2016. Naringenin inhibits proliferation, migration, and invasion as well as induces apoptosis of gastric cancer SGC7901 cell line by downregulation of AKT pathway. Tumor Biology. 37: 11365-11374.

Bilkan MT, Şahin O, Yurdakul Ş, 2017. Experimental and DFT studies of solvent effects on molecular structure and physical properties of Dipyridylamine pyridine based ligand, Journal of Molecular Structure. 1133: 580-590. 
Cavia-Saiz M, Busto MD, Pilar-Izquierdo MC, Ortega N, Perez-Mateos M, Muñiz P, 2010. Antioxidant properties, radical scavenging activity and biomolecule protection capacity of flavonoid naringenin and its glycoside naringin: a comparative study. Journal of the Science of Food and Agriculture, 90: 1238-1244.

Choi C, Kertez M, Conformational information from vibrational spectra of styrene, trans-stilbene, and cis-stilbene, Journal of Physical Chemistry A, 101: 3823-3831.

Dennington RD, Keith TA, Millam JM, 2008. GaussView 5, Gaussian, Inc.

Frabasile S, Koishi AC, Kuczera D, Silveira GF, Verri Jr WA, dos Santos CND, Bordignon J, 2017. The citrus flavanone naringenin impairs dengue virus replication in human cells. Scientific Reports-Nature. 7:41864-41874.

Frisch MJ, Trucks GW, Schlegel HB, et al. 2004. Gaussian, Inc., Gaussian 03, Revision D.01. Wallingford CT.

Fuhr U, Klittich K, Horst Staib A, 1993. Inhibitory effect of grapefruit juice and its bitter principal, naringenin, on CYP1A2 dependent metabolism of caffeine in man. British Journal of Clinical Pharmacology. 35:431-436.

Ghofrani S, Joghataei MT, Mohseni S, Baluchnejadmojarad T, Bagheri M, Khamse S, Roghani M, 2015. Naringenin improves learning and memory in an Alzheimer's disease rat model: Insights into the underlying mechanisms. European Journal of Pharmacology. 5:195-201.

Gonzales GB, Smagghe G, Wittevrongel J, Huynh NT, Van Camp J, Raes K, 2016. Metabolism of Quercetin and Naringenin by Food-Grade Fungal Inoculum, Rhizopus azygosporus Yuan et Jong (ATCC 48108). Journal of Agricultural Food Chemistry 49: 9263-9267.

Jamróz MH, 2004. Vibrational energy distribution analysis. VEDA 4. Warsaw.
Lee SY, Boo BH, 1996. Molecular Structures and Vibrational Spectra of Pyrrole and Carbazole by Density Functional Theory and Conventional ab Initio Calculations, Journal of Physical Chemistry A. 100: 15073-15078.

Parr RG, Szentpa'Ly LV, Liu S, 1999. Electrophilicity Index, Journal of American Chemical Society, 121: 1922-1924.

Pauling L, 1960. The nature of the chemical bond, (Cornell University Press).

PC H, Saville DJ, 2001. Inhibition of human CYP3A4 activity by grapefruit flavonoids, furanocoumarins and related compounds. Journal of Pharmacy \& Pharmaceutical Sciences. 4: 217-227.

Saqib M, Iqbal S, Mahmood A, Akram R, 2015. Theoretical Investigation for Exploring the Antioxidant Potential of Chlorogenic Acid: A Density Functional Theory Study, International Journal of Food Properties, 19: 745-751.

Shin W, Lah MS, 1986. Structure of (R,S)-naringenin, Acta. Crystallographica C, 42: 626-627.

Swanson BN, 1985. Medical use of dimethyl sulfoxide (DMSO). Reviews in Clinical \& Basic Pharmacology. 5: 1-33.

Tomasi J, Mennucci B, Cammi R, 2005. Quantum mechanical continuum solvation models, Chemical Reviews. 105: 2999-3094.

Unsalan O, Erdogdu Y, Gulluoglu MT, 2009. FTRaman and FT-IR spectral and quantum chemical studies on some flavonoid derivatives: Baicalein and Naringenin, Journal of Raman Spectroscopy. 40: 562-570.

Zhang L, Song L, Zhang P, Liu T, Zhou L, Yang G, Lin R, Zhang J, 2015. Solubilities of Naringin and Naringenin in Different Solvents and Dissociation Constants of Naringenin, Journal of Chemical \& Engineering Data. 60: 932-940.

Zhang P, Lin R, Yang G, Zhang J, Zhou L, Liu T, 2013. Solubility of Naringenin in Ethanol and Water Mixtures, Journal of Chemical \& Engineering Data. 58: 2402-2404. 